\title{
Evidence for the therapeutic effect of the organic content in Szigetvár thermal water on osteoarthritis: a double-blind, randomized, controlled clinical trial
}

\author{
Adrienn Hanzel ${ }^{1} \cdot$ Károly Berényi $^{1} \cdot$ Krisztina Horváth $^{2} \cdot$ Katalin Szendi $^{1} \cdot$ Balázs Németh $^{1} \cdot$ Csaba Varga $^{1}$
}

Received: 13 October 2018 / Revised: 15 January 2019 / Accepted: 15 January 2019 / Published online: 7 February 2019

(C) The Author(s) 2019

\begin{abstract}
The therapeutic effects of mineral waters have been attributed to the inorganic components alone; however, biologically active organic components are also present. We aimed to investigate whether the healing effect of Szigetvár thermal mineral water could relate to the organic matter in patients suffering from osteoarthritis of the hips and the knees. XAD macroreticular resins were used to prepare the organic fraction. Patients received a 30-min thermal water $\left(34^{\circ} \mathrm{C}\right)$ treatment in a bath tub, five times a week for 3 weeks. After randomization, patients were divided into three groups: tap water, mineral water, and organic fraction group. Primary outcomes were range of movement (ROM), Western Ontario and McMaster University Osteoarthritis Index (WOMAC), and visual analog scale (VAS) for pain severity, and the Short Form 36 (SF-36) questionnaire was used. These scores and indices were measured at baseline, after the last treatment, and at the end of the 3-month follow-up period. Seventy-four patients (age $67.3 \pm 4.48$ years) were enrolled: tap water $n=24$, mineral water $n=26$, and organic fraction $n=24$. Treatment with the redissolved organic fraction significantly improved ROM, WOMAC, and SF-36 scores compared to the tap water. Our clinical trial provided evidence for the beneficial health effects of the organic fraction of Szigetvár medicinal water.
\end{abstract}

Keywords Balneotherapy $\cdot$ Arthritis $\cdot$ Thermal water $\cdot$ Organic fraction $\cdot$ ROM $\cdot$ WOMAC $\cdot$ Double-blind

\section{Introduction}

Previous studies have shown the beneficial effects of balneotherapy in musculoskeletal (chronic low back pain, rheumatoid arthritis, etc), gynecological, and dermatological conditions (psoriasis in particular); peripheral vascular disease; fibromyalgia; and many other disorders (Ayán et al. 2017; Bender et al. 2014; Fioravanti et al. 2018; Hanzel et al. 2018; Karagülle et al. 2018; Péter et al. 2017).

Thanks to its special geothermal conditions and great natural power, Hungary is one of the leading countries worldwide using thermal water for medical purposes.

Katalin Szendi

szkata82@yahoo.co.uk

1 Department of Environmental Health, Institute of Public Health Medicine, Medical School, University of Pécs, 12 Szigeti str., Pécs 7624, Hungary

2 Hospital of Szigetvár, Szigetvár, Hungary
Hungary is rich in thermal mineral waters as it has more than 1300 thermal wells. From the eighteenth century, chemical analyses focused mainly on the inorganic substances of natural thermal mineral waters, and therefore, these waters were categorized according to their inorganic compositions. Mineral waters are defined as waters containing more than $1000 \mathrm{mg}$ of total dissolved solids (Ministry of Health Decree no. 74/1999 (XII. 25.)), and thermal waters have to reach the temperature of more than $30{ }^{\circ} \mathrm{C}$ (General Directorate of Water Management n.d.). In the second half of the twentieth century, several analytical methods were developed to analyze the organic compounds of medicinal waters (Kárpáti et al. 1999; Kompanichenkoa et al. 2016). Still, the presence of organic components was almost completely ignored both in the categorization of thermal mineral waters and their mechanism of action. We could not find any publications investigating the effects of the organic compounds of medicinal waters on diseases.

Osteoarthritis (OA), the most common musculoskeletal condition of aged population, is a chronic degenerative disease involving large weight-bearing joints resulting in 
stiffness, pain, and impaired movement. The 2010 Global Burden of Disease Study reports that the burden of musculoskeletal disorders accounts for $6.8 \%$ of DALYs worldwide (Lozano et al. 2012). OA can affect any joints, but most commonly develops in the hips, knees, and hands. Its prevalence is $18.3 \%$ in Hungary (Musculoskeletal Health in Europe: Report v5.0. European Musculoskeletal Conditions Surveillance and Information Network 2012.), higher than the worldwide estimates $(9.6 \%$ of men and $18.0 \%$ of women aged over 60 years) (WHO Department of Chronic Diseases and Health Promotion n.d.), and it is increasing due to aging and related factors such as obesity. OA has a significant negative impact on patients' quality of life. The goals of OA treatment include alleviation of pain and improvement of functional status. Nonpharmacological therapies are very important in OA together with pharmacological treatments. These treatments should be individually devised and should undergo rigorous randomized controlled trials in a similar manner to pharmacological studies. One of the widely used nonpharmacological treatment options is balneotherapy. The beneficial effects of the thermal mineral waters and/or medicinal mud on OA were investigated by several randomized controlled trials. However, these studies were focusing on the inorganic compounds of the thermal mineral waters (Branco et al. 2016; Fioravanti et al. 2014; Fioravanti et al. 2015; Kovacs et al. 2012; Kulisch et al. 2014).

In our previous clinical trial (Hanzel et al. 2018), we have already proven the positive health effects of Szigetvár thermal mineral water on patients suffering from osteoarthritis of the hips and the knees. Several other studies did the same with other thermal waters, spa therapies (Pittler et al. 2006; Franke et al. 2007; Kulisch et al. 2009; Horvath et al. 2012). In a recent systematic review, Morer et al. described these health effects as well and emphasized that double-blind randomized clinical trials are needed to study the role of mineral elements and other chemical compounds appropriately (Morer et al. 2017).

Fulfilling this requirement, the aim of the present study was to assess the therapeutic effect of the organic fraction of Szigetvár thermal mineral water in a double-blind, randomized, controlled clinical trial on patients suffering from OA of the hips and the knees. This is a completely new approach providing insight into the mechanism of action of thermal mineral waters.

\section{Patients and methods}

We performed the study again at Szigetvár Spa between August 2015 and September 2017, at the same place like we did it in our previous study (Hanzel et al. 2018). The same Regional Ethics Committee of University of Pécs, Hungary, approved the study protocol (Permission No.
5351), in accordance with the 2008 Helsinki declaration. The study was observed by medical professionals.

Inclusion and exclusion criteria were the same as in our previous study (Hanzel et al. 2018) to ensure comparability with our former results. All experimental circumstances had to be the same to prove our hypothesis that the beneficial effects of medicinal waters originate from their organic components.

Regular medications of comorbidities were administered to the patients as usual.

We paid special attention to include only those patients who had never received underwater jet massage either with tap water, or with medical water.

\section{Recruitment of patients}

The maximum travel distance required for involved patients to reach the spa was $15 \mathrm{~km}$, to minimalize dropout. Informed written consent was obtained from every patient. Parameters applied in patient selection were age, sex, and diseases. The sample size had to be comparable to the sample size of our previous study (Hanzel et al. 2018). A sample size of 24 patients in the organic fraction group was required. Patient recruitment was continued until reaching 24 patients.

\section{Preparation of organic fraction}

Organic concentrate from medicinal water was prepared according to Varga (1991). Samples of thermal mineral water concentrates were isolated by adsorption-elution cycles on macroreticular adsorbent resins. A stainless steel pilot chromatography column (size $103.5 \mathrm{~mm} \times 1000 \mathrm{~mm}$, own product) was filled with a mixture of two adsorbent resin types (XAD4 (Serva) and XAD-1180 (Rohm\&Haas) in a rate of 1:1 in a volume of 5 1). Fifty cubic meters of thermal mineral water was passed over the column at an average flow rate of 1 bed volume per minute. Inert gas was used to eliminate the residual water from the column. Adsorbed organic substances were eluted with $96 \%$ ethanol of 1 bed volume to produce a 5000 -fold concentration of the original thermal mineral water. The concentrate contained the vast majority of organic substances of the water, but not inorganic components. During the jet massage treatment in bath tub, the organic concentrate was diluted to the original concentration and temperature with tap water.

\section{Interventions}

We applied the same protocol like in our former study (Hanzel et al. 2018). Patients received a 30 -min thermal water $\left(34^{\circ} \mathrm{C}\right)$ treatment in a bath tub, 5 times a week for 3 weeks. (Patients received solely underwater jet massage treatment (15 min per occasion) in tubs; afterwards, they stayed another $15 \mathrm{~min}$ in the tub.) All treatments were performed ambulatory. 


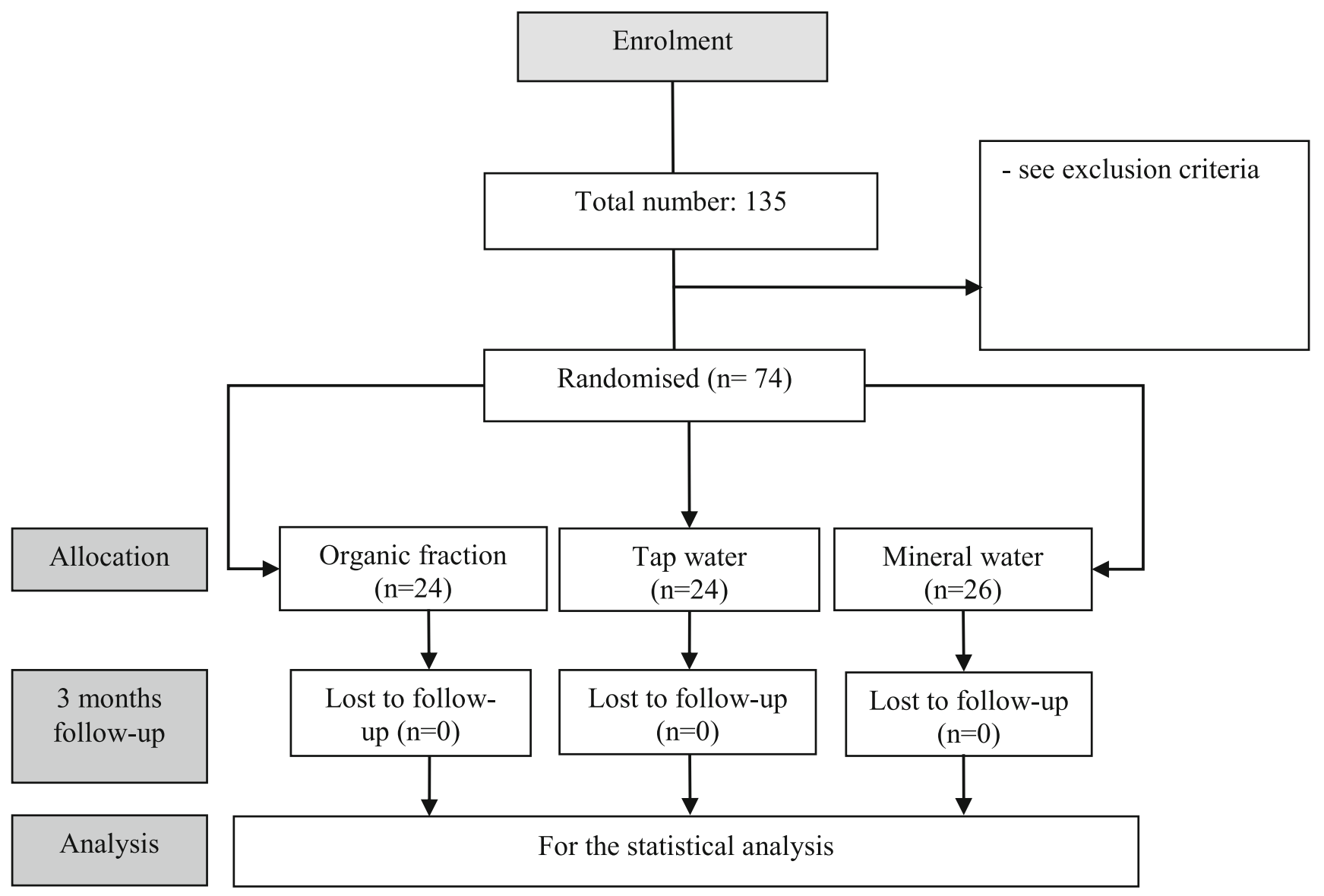

Fig. 1 Study flowchart

Analgesic medications were suspended during the 3-weeklong treatment. Patients were randomly divided into three groups according to the type of the water used for the treatment. Tap water group patients received the jet treatment in tap water, mineral water group patients were treated in thermal mineral water (see Hanzel et al. 2018), and the third group in tap water containing the redissolved organic concentrate. All the three water types were colored by commercially available water coloring tablets to minimalize the experienced difference between the three different types of waters. Treatments were carried out in the same room; hence, all patients smelled the odor of the thermal water. With proper $\mathrm{pH}$ adjustment, differences in sensation were also eliminated. All treatments were performed in individual bathtubs. Water temperature was $34{ }^{\circ} \mathrm{C}$. Neither the patients nor the investigators knew which type of water was filled in the tub; this was only known by the study assistant. A medical professional was responsible for the examination of patients, taking the medical history and selection.

\section{Outcome parameters}

Patients' condition was measured with both objective and subjective methods like in our previous study (Hanzel

Table 1 Clinical characteristics of the patients. BMI, body mass index

\begin{tabular}{|c|c|c|c|c|}
\hline & Tap water $(n=24)$ (Hanzel et al. 2018) & Mineral water $(n=26)$ (Hanzel et al. 2018) & Organic fraction $(n=24)$ & $p$ value \\
\hline Mean age (years) & $67.43 \pm 4.95$ & $66.22 \pm 4.68$ & $68.46 \pm 3.58$ & 0.206 \\
\hline Male, $n(\%)$ & $8(33.3)$ & $9(34.6)$ & $7(29.2)$ & 0.912 \\
\hline BMI $\left(\mathrm{kg} / \mathrm{m}^{2}\right)$ & $27.08 \pm 3.42$ & $26.66 \pm 3.05$ & $26.33 \pm 3.19$ & 0.725 \\
\hline Diabetes type $2, n(\%)$ & $12(50)$ & $13(50)$ & $11(45.8)$ & 0.908 \\
\hline Hypertension, $n(\%)$ & $18(75)$ & $20(76.9)$ & $17(70.8)$ & 0.850 \\
\hline
\end{tabular}

Comparing the three groups, no significant differences were found between age, sex distribution, body mass index, and number of hypertensive patients. Mean age, years, and BMI estimates are from Kruskal-Wallis test; and Male, Diabetes, and Hypertension estimates are from chi-square test 
Table 2 Baseline, short-term, and long-term measurements in range of joint movements

\begin{tabular}{llll}
\hline & \multicolumn{2}{l}{ Organic fraction } & \\
\cline { 2 - 4 } & Mean & Std. deviation & $p$ value \\
\hline Hip flexion before treatment & 102.38 & 5.35 & \\
Hip flexion after 3 weeks & 109.46 & 5.21 & 0.001 \\
Hip flexion after 3 months & 108.00 & 5.00 & 0.015 \\
Hip extension before treatment & 6.54 & 2.70 & \\
Hip extension after 3 weeks & 4.77 & 1.92 & 0.004 \\
Hip extension after 3 months & 5.46 & 1.90 & 0.02 \\
Hip abduction before treatment & 25.08 & 4.09 & \\
Hip abduction after 3 weeks & 28.23 & 5.05 & 0.001 \\
Hip abduction after 3 months & 26.92 & 4.86 & 0.004 \\
Hip adduction before treatment & 108.91 & 11.92 & \\
Hip adduction after 3 weeks & 115.18 & 10.03 & 0.001 \\
Hip adduction after 3 months & 114.09 & 9.74 & 0.003 \\
Knee flexion before treatment & 7.18 & 2.36 & \\
Knee flexion after 3 weeks & 4.82 & 1.47 & 0.003 \\
Knee flexion after 3 months & 5.18 & 1.54 & 0.003 \\
Knee extension before treatment & 102.38 & 5.35 & \\
Knee extension after 3 weeks & 109.46 & 5.21 & 0.003 \\
Knee extension after 3 months & 108.00 & 5.00 & 0.005 \\
\hline
\end{tabular}

Baseline values were compared to short-term values, and baseline values were compared to long-term values. All estimates are from Wilcoxon signed-rank test

et al. 2018) to be able to compare the possible beneficial effects of the redissolved organic concentrate with the healing effect of medicinal water or tap water control. Range of movement (ROM) (Soucie et al. 2010) of the involved joints, Western Ontario and McMaster University Osteoarthritis Index (WOMAC) (Péntek et al. 1999), visual analog scale (VAS) for pain severity (Gould et al. 2001), and Short Form 36 questionnaire (SF-36) (Czimbalmos et al. 1999) were applied. ROM score, WOMAC index, and VAS were measured before the first treatment (baseline), after the last treatment (short-term), and at the end of the 3-month follow-up period (longterm). SF-36 questionnaire was filled in before the first treatment and after the last treatment. Interobserver error was also ruled out (Hanzel et al. 2018). Goniometer was used to measure movement of the joints; the mean value of three measurements was documented for further calculation. Goniometry plays an essential role in the clinical measurement of range of motion (Gajdosik and Bohannon 1987; Pazira et al. 2016). It is apparent from several papers that traditional plastic goniometer evaluates hip and knee joint angles efficiently and reliably; however, use of goniometer requires careful attention in evaluation (Kim 2018; Marques et al. 2017; Charbonnier et al. 2015; Gajdosik and Bohannon 1987; Rheault et al. 1988).

\section{Randomization}

Random number generator was used to allocate the patients into groups upon arrival (Suresh 2011).

\section{Statistical analysis}

Statistical analyses were performed with IBM SPSS Statistics for Windows Version 22 (IBM Corp., New York, NY, USA). Significance of the results was analyzed by Kruskal-Wallis, Mann-Whitney, Wilcoxon signedrank test, and chi square tests. $p<0.05$ was considered the criterion of significance.

\section{Results}

Among 135 patients, suffering from OA of the hips and the knees, enrolled into the study 61 were excluded and 74 (24 males, 50 females, mean age $67.3 \pm 4.48$ years) were randomized and treated (Fig. 1). After randomization, patients were divided into three groups according to the water type used for treatment: tap water group $(n=24)$, mineral water group $(n=26)$, and organic fraction group $(n=24)$. Table 1 shows the clinical characteristics of the patient groups. Comparing the three groups, there were no significant differences between age, sex distribution, body mass index, and number of hypertensive patients.

\section{ROM score}

\section{Baseline-short-term-long-term comparison of the effect of organic fraction}

There were significant ROM changes in the organic fraction group. Hip flexion $(p=0.001)$, hip extension $(p=$ $0.004)$, hip abduction $(p=0.001)$, hip adduction $(p=$ $0.001)$, knee flexion $(p=0.003)$, and knee extension $(p=0.003)$ showed significant improvement when baseline values were compared to short-term values. Furthermore, when comparing baseline values to longterm values, hip flexion $(p=0.015)$, hip extension $(p=$ $0.020)$, hip abduction $(p=0.004)$, hip adduction $(p=$ $0.003)$, knee flexion $(p=0.003)$, and knee extension $(p=0.005)$ showed significant improvement (Table 2).

\section{Tap water-mineral water-organic fraction comparison}

When comparing the ROM measured in the organic fraction group to the ROM measured in the tap water group after 15 treatments, significant improvements were detected in all parameters, except changes in hip extension. We 
performed the same comparison between the organic fraction and the mineral water group. There was no significant change in parameters (Fig. 2).

When comparing the ROM of organic fraction group patients to the ROM of tap water group patients after 3 months, significant improvements were detected in all parameters (hip flexion $p=0.028$, hip abduction $p=$ 0.004 , hip adduction $p=0.002$, knee flexion and extension $p<0.001)$, except changes in hip extension $(p=$ $0.059)$. But only knee flexion had a significant difference $(p=0.027)$ in the value of organic fraction group compared to the mineral water group (Fig. 3).

\section{WOMAC score}

\section{Baseline-short-term-long-term comparison of the effect of organic fraction}

Patients in the organic fraction group presented significant improvement in the dimensions of the WOMAC score during the short-term period, and in the long-term period, as well, except stiffness parameter. Table 3 shows the organic fraction group's detailed WOMAC index results.

\section{Tap water-mineral water-organic fraction comparison}

Comparing the WOMAC scores determined in the organic fraction group to the tap water group, no significant differences were detected in the short-term. However, 3 months after the treatment, we found significant improvements in the organic fraction group concerning pain $(p=0.004)$, activity $(p<0.001)$, and the WOMAC total score $(p<0.001)$ (Table 4).

Comparing the organic fraction group to the mineral water group in the short-term period, significant difference was not found in pain $(p=0.551)$, stiffness $(p=$ $0.521)$, activity $(p=0.399)$, and total $(p=0.749)$ WOMAC scores. In the long-term period, there were no significant differences, either (Table 4).
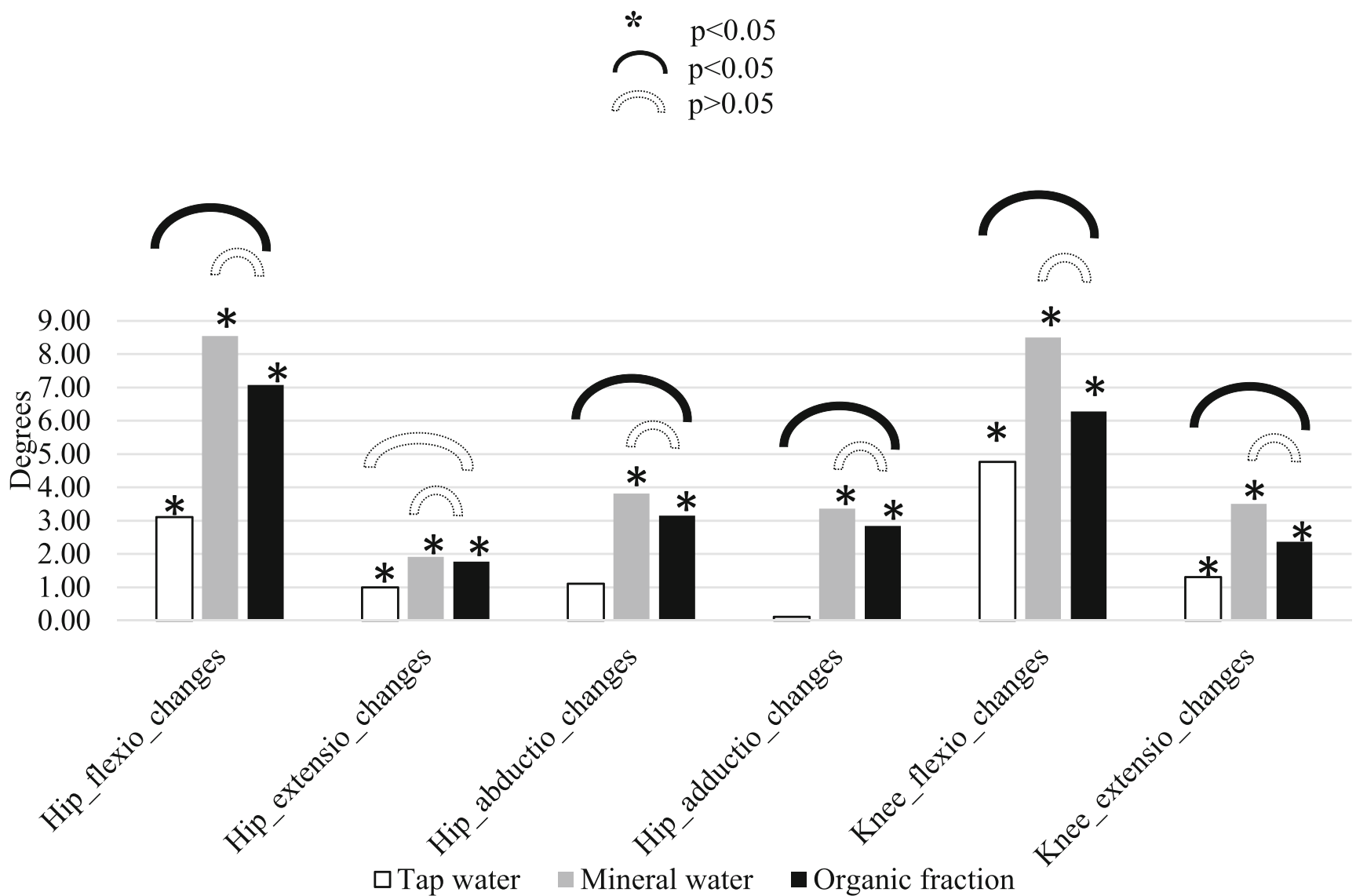

Fig. 2 Short-term changes in range of joint movements (ROM). Organic fraction group was compared to tap water and mineral water group after 15 treatments. $*$ The three types of waters causing statistically significant changes in ROM parameters short-term. All estimates are from Wilcoxon signed-rank test. $\frown$ Statistically significant changes between groups. All estimates are from Mann-Whitney test. cant difference between groups. All estimates are from Mann-Whitney test 

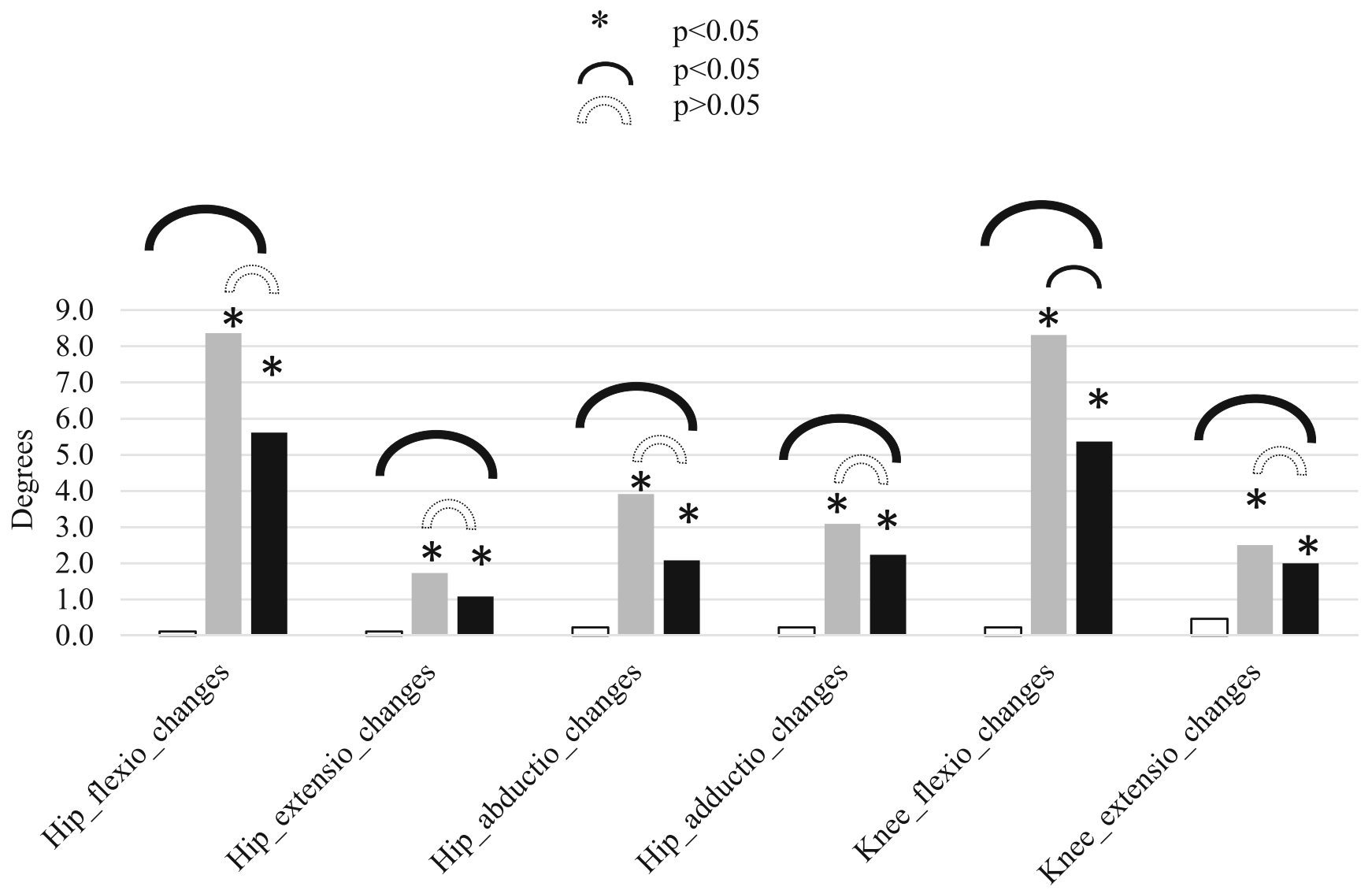

$\square$ Tap water $\square$ Mineral water $\square$ Organic fraction

Fig. 3 Long-term changes in range of joint movements (ROM). Organic fraction group was compared to tap water and mineral water group after 3 months.*The three types of waters causing statistically significant changes in ROM parameters short-term. All estimates are from

\section{SF 36 questionnaire}

\section{Baseline-short-term-long-term comparison of the effect of organic fraction}

We found improvement in all dimensions of the SF 36 questionnaire, except in the dimension of "General health perceptions," both short- and long-term. The "Emotional role
Wilcoxon signed-rank test. $\frown$ Statistically significant changes between groups. All estimates are from Mann-Whitney test. No statistically significant difference between groups. All estimates are from MannWhitney test

functioning" dimension showed positive change only in the long-term period.

\section{Tap water-mineral water-organic fraction comparison}

Three months after the treatment, there were significant improvements only in the dimension of "Physical functioning" when comparing the results of the SF 36

Table 3 WOMAC scores in the organic fraction group

\begin{tabular}{|c|c|c|c|c|c|c|c|c|c|}
\hline & \multirow[t]{2}{*}{ Parameter } & \multicolumn{2}{|c|}{ Before treatment (baseline) } & \multicolumn{2}{|c|}{ After 3 weeks (short-term) } & \multirow[t]{2}{*}{$p$ value } & \multicolumn{2}{|c|}{ After 3 months (long-term) } & \multirow[t]{2}{*}{$p$ value } \\
\hline & & Mean & \pm Std. deviation & Mean & \pm Std. deviation & & Mean & \pm Std. deviation & \\
\hline \multirow[t]{4}{*}{ Organic fraction } & WOMAC pain score & 6.83 & 2.07 & 4.71 & 1.80 & $<0.001$ & 4.96 & 1.85 & 0.001 \\
\hline & WOMAC stiffness score & 1.83 & 1.49 & 1.00 & 0.93 & 0.001 & 1.83 & 1.34 & 1.000 \\
\hline & WOMAC activity score & 26.62 & 8.64 & 18.46 & 7.59 & $<0.001$ & 19.708 & 7.07 & $<0.001$ \\
\hline & WOMAC total score & 35.29 & 10.36 & 24.17 & 9.06 & $<0.001$ & 26.50 & 8.18 & $<0.001$ \\
\hline
\end{tabular}

Baseline values were compared to short-term values, and baseline values were compared to long-term values. All estimates are from Wilcoxon signedrank test 
Table 4 WOMAC scores comparing organic fraction group to tap water and mineral water groups

\begin{tabular}{|c|c|c|c|c|c|c|c|c|}
\hline \multirow[t]{2}{*}{ Parameter } & \multicolumn{2}{|c|}{$\begin{array}{l}\text { Tap water (Hanzel } \\
\text { et al. 2018) }\end{array}$} & \multicolumn{2}{|c|}{$\begin{array}{l}\text { Mineral water } \\
\text { (Hanzel et al. 2018) }\end{array}$} & \multicolumn{2}{|c|}{ Organic fraction } & \multirow{2}{*}{$\begin{array}{l}\text { Organic fraction } \\
\text { vs tap water } \\
p \text { value }\end{array}$} & \multirow{2}{*}{$\begin{array}{l}\text { Organic fraction vs } \\
\text { mineral water } \\
p \text { value }\end{array}$} \\
\hline & Mean & $\begin{array}{l} \pm \text { Std. } \\
\text { deviation }\end{array}$ & Mean & $\begin{array}{l} \pm \text { Std. } \\
\text { deviation }\end{array}$ & Mean & $\begin{array}{l} \pm \text { Std. } \\
\text { deviation }\end{array}$ & & \\
\hline $\begin{array}{l}\text { WOMAC pain score diff. } \\
3 \text { weeks }\end{array}$ & 1.909 & 3.866 & 2.320 & 3.250 & 2.125 & 2.455 & 0.649 & 0.551 \\
\hline $\begin{array}{l}\text { WOMAC stiffness score diff. } \\
3 \text { weeks }\end{array}$ & 1.091 & 1.743 & 1.000 & 1.581 & 0.833 & 1.129 & 0.485 & 0.521 \\
\hline $\begin{array}{l}\text { WOMAC activity score diff. } \\
3 \text { weeks }\end{array}$ & 6.545 & 10.613 & 6.600 & 7.089 & 8.167 & 6.850 & 0.316 & 0.399 \\
\hline $\begin{array}{l}\text { WOMAC total score diff. } \\
3 \text { weeks }\end{array}$ & 9.545 & 14.097 & 9.920 & 8.831 & 11.125 & 9.611 & 0.27 & 0.749 \\
\hline $\begin{array}{l}\text { WOMAC pain score diff. } \\
3 \text { months }\end{array}$ & 0.045 & 1.090 & 2.520 & 2.694 & 1.875 & 2.525 & 0.004 & 0.332 \\
\hline $\begin{array}{l}\text { WOMAC stiffness score diff. } \\
3 \text { months }\end{array}$ & 0.045 & 0.653 & 0.040 & 0.539 & 0.000 & 0.659 & 0.668 & 0.632 \\
\hline $\begin{array}{l}\text { WOMAC activity score diff. } \\
3 \text { months }\end{array}$ & 0.136 & 1.754 & 6.080 & 7.000 & 6.917 & 6.852 & $<0.001$ & 0.631 \\
\hline $\begin{array}{l}\text { WOMAC total score diff. } \\
3 \text { months }\end{array}$ & 0.227 & 2.266 & 8.640 & 7.713 & 8.792 & 9.012 & $<0.001$ & 0.992 \\
\hline
\end{tabular}

Organic fraction group was compared to tap water and mineral water group. All estimates are from Mann-Whitney test

questionnaire of organic fraction group to the tap water group $(p=0.020)$.

\section{VAS}

\section{Baseline-short-term-long-term comparison of the effect of organic fraction}

Regarding the results of VAS, redissolved organic fraction treatment significantly reduced the pain both in short-term $(p=<0.001)$ and long-term $(p=0.025)$. Figure 4 shows changes of pain measured by VAS together with the previous results of tap water group and mineral water group (Hanzel et al. 2018).

\section{Tap water-mineral water-organic fraction comparison}

There were no significant differences when comparing organic fraction group to tap water group or mineral water group, either in short-term $(p=0.107 ; p=0.670)$ or in long-term $(p=$ $0.525 ; p=0.564)$.

\section{Discussion}

This double-blind, randomized, controlled clinical trial proved the therapeutic effect of the redissolved organic fraction of the Szigetvár mineral water according to international standards in patients suffering from $\mathrm{OA}$ of the knee and hip. To the best of our knowledge, previous researches were only limited to the inorganic components of the thermal mineral water, e.g., sulfur (Kovacs et al. 2012; Carbajo and Maraver 2017), $\mathrm{Rn}^{222}$ (Nagy et al. 2009a; Nagy et al. 2009b), Dead Sea salt solution (Holló et al. 2004), and $\mathrm{CO}_{2}$ (Fabry et al. 2009) in humans. No researcher has examined the possible healing effects of the organic fractions of mineral waters.

Along our initial hypothesis, the redissolved organic substance concentrate could partially provide the therapeutic effect of the original medicinal water. Our finding is the first direct evidence for the so-called Varga's organic hypothesis (Varga and Szuetta 2009; Varga 2010; Varga 2012), namely that the biological effects of thermal waters are caused by bioactive organic molecules more likely than by the inorganic salt content. Inorganic ion absorption through the skin is either unproven or insignificant due to higher ion concentrations in the human body. (This does not apply to the high-ionic mineral water consumption as course of treatment.) However, for example, hormone-like molecules with high biological activity can be found among the organic substances. These molecules that are absorbed can be highly active at very low concentrations. Furthermore, Bender et al. (2014) in their meta-analysis concluded that the beneficial effects of Hungarian thermal mineral waters were independent of their inorganic salt content.

Interpreting ROM results, when only the effect of the redissolved organic fraction was examined short- and longterm, it caused significant improvements in ROM score, just like in our previous study where the possible beneficial effects 


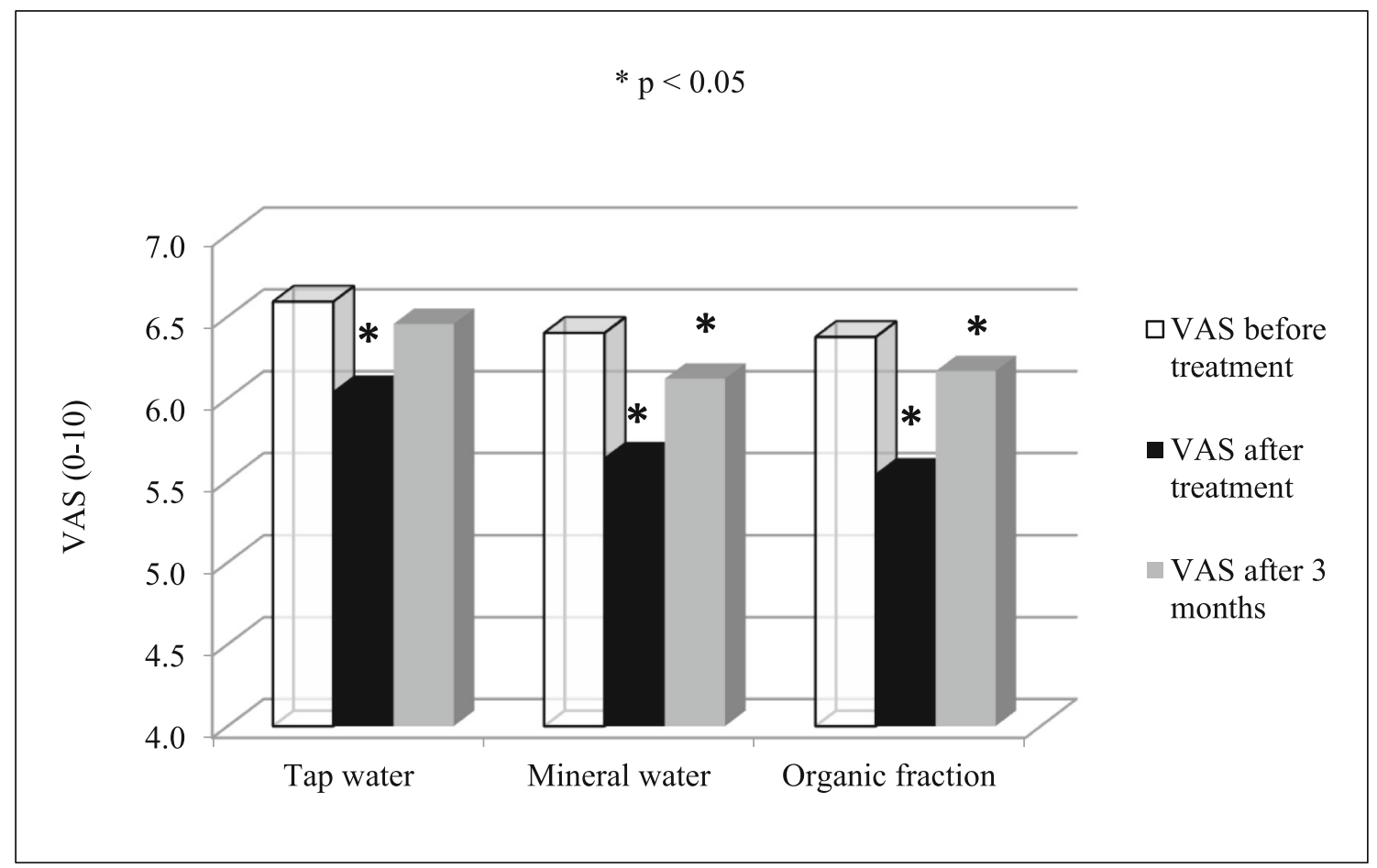

Fig. 4 Changes of pain measured by visual analog scale (VAS). Results of tap water and mineral water are from Hanzel et al. (2018). All estimates are from Wilcoxon signed-rank test. * Statistically significant reduction of pain

of the original mineral water were studied (Hanzel et al. 2018). So, in this case, the positive effect of the concentrate is very similar. When the three groups were compared, changes in ROM scores were higher in the organic fraction group than in the tap water group, both in short- and long-term. Results refer again to the same favorable effect of the redissolved organic fraction as the original mineral water, both short- and long-term.

WOMAC scores also indicated significant positive effects in the organic fraction group, short- and long-term, too. Comparing the three types of water-treated group, tap water group showed significantly worse WOMAC scores after 3 months of followup than the organic fraction group. WOMAC scores indicated similar beneficial or no effects of the mineral water compared to the organic fraction, both short- and long-term.

In several dimensions of the SF 36 questionnaire, the organic fraction induced positive changes both short- and longterm.

Regarding the VAS results, the organic fraction decreased the pain severity significantly also short- and long-term.

These novel findings emphasize the role and positive effects of the organic fraction of Szigetvár thermal mineral water.

\section{Limitations}

Questionnaires were self-reported; this could lead to misunderstanding and bias. Some other objective outcome parameters could have been involved, such as biomarkers of inflammation or oxidative stress. Higher number of patients could increase the strength of evidence.

\section{Conclusion}

On the field of balneology science, this unique idea is to suggest the beneficial healing effects of the organic substances in Szigetvár thermal mineral water. However, this phenomenon also needs to be proven in other medicinal waters. Once it is confirmed in numerous other investigations, our theory can lead to paradigm shift in the science of balneology. The line of further research is set for our team, as several medicinal waters in Hungary contain considerable amount of organic matter according to previous gas chromatography studies (Varga 2010). The presented concentration method also provides the opportunity to produce medicinal water-based products with therapeutic effects, which can be used both bedside and homeside.

Acknowledgments Open access funding provided by University of Pécs (PTE). The authors want to express their special thanks to Ms. I. BarhóBarbarics and Mr. G. Budai and M. Bein. The present scientific contribution is dedicated to the 650th anniversary of the foundation of the University of Pécs, Hungary.

Funding information This work was financially supported by the Medical School, University of Pécs (PTE ÁOK-KA-2016/34039), Hungary. Balázs Németh was supported by the ÚNKP-18-3-III New 
National Excellence Program of the Ministry of Human Capacities, Hungary (http://www.kormany.hu/hu/emberieroforrasokminiszteriuma). The publication of this manuscript was supported by the "EFOP-3.6.3VEKOP-16-2017-00009" grant. The funder had no role in the study design, data collection and analysis, decision to publish, or preparation of the manuscript.

\section{Compliance with ethical standards}

The Regional Ethics Committee of University of Pécs, Hungary, approved the study protocol (Permission No. 5351), in accordance with the 2008 Helsinki declaration.

Conflict of interests The authors declare that they have no conflict of interest.

Open Access This article is distributed under the terms of the Creative Commons Attribution 4.0 International License (http:// creativecommons.org/licenses/by/4.0/), which permits unrestricted use, distribution, and reproduction in any medium, provided you give appropriate credit to the original author(s) and the source, provide a link to the Creative Commons license, and indicate if changes were made.

\section{References}

Ayán C, Carvalho P, Varela S, Cancela JM (2017) Effects of water-based exercise training on the cognitive function and quality of life of healthy adult women. J Phys Act Health 14:899-904. https://doi. org/10.1123/jpah.2017-003

Bender T, Bálint G, Prohászka Z, Géher P, Tefner IK (2014) Evidencebased hydro- and balneotherapy in Hungary - a systematic review and meta-analysis. Int J Biometeorol 58:311-323. https://doi.org/10. 1007/s00484-013-0667-6

Branco M, Rêgo NN, Silva PH, Archanjo IE, Ribeiro MC, Trevisani VF (2016) Bath thermal waters in the treatment of knee osteoarthritis: a randomized controlled clinical trial. Eur J Phys Rehabil Med 52: 422-430 26899038

Carbajo JM, Maraver F (2017) Sulphurous mineral waters: new applications for health. Evid Based Complement Alternat Med 2017:1-11. https://doi.org/10.1155/2017/8034084

Charbonnier C, Chagué S, Schmid J, Kolo FC, Bernardoni M, Christofilopoulos P (2015) Analysis of hip range of motion in everyday life: a pilot study. Hip Int 25:82-90. https://doi.org/10.5301/ hipint.5000192

Czimbalmos Á, Nagy Z, Varga Z, Husztik P (1999) Páciens megelégedettségi vizsgálat SF-36 kérdőívvel, a magyarországi normálértékek meghatározása. Népegészségügy 80:4-19

Fabry R, Monnet P, Schmidt J, Lusson JR, Carpentier PH, Baguet JC, Dubray C (2009) Clinical and microcirculatory effects of transcutaneous $\mathrm{CO} 2$ therapy in intermittent claudication. Randomized double-blind clinical trial with a parallel design. Vasa 38:213-224. https://doi.org/10.1024/0301-1526.38.3.213

Fioravanti A, Tenti S, Giannitti C, Fortunati NA, Galeazzi M (2014) Short- and long-term effects of mud-bath treatment on hand osteoarthritis: a randomized clinical trial. Int J Biometeorol 58:79-86. https://doi.org/10.1007/s00484-012-0627-6

Fioravanti A, Manica P, Bortolotti R, Cevenini G, Tenti S, Paolazzi G (2018) Is balneotherapy effective for fibromyalgia? Results from a 6-month double-blind randomized clinical trial. Clin Rheumatol 37: 2203-2212. https://doi.org/10.1007/s10067-018-4117-z

Fioravanti A, Bacaro G, Giannitti C, Tenti S, Cheleschi S, Gui Delli GM et al (2015) One-year follow-up of mud-bath therapy in patients with bilateral knee osteoarthritis: a randomized, single-blind controlled trial. Int J Biometeorol 59:1333-1343. https://doi.org/10.1007/ s00484-014-0943-0

Franke A, Reiner L, Resch KL (2007) Long-term benefit of radon spa therapy in the rehabilitation of rheumatoid arthritis: a randomised, double-blinded trial. Rheumatol Int 27:703-713. https://doi.org/10. 1007/s00296-006-0293-2

Gajdosik RL, Bohannon RW (1987) View correspondence clinical measurement of range of motion. Review of goniometry emphasizing reliability and validity. Phys Ther 67:1867-1872

General Directorate of Water Management, website: http://www.ovf.hu/ hu/vizrajzi-fogalomtar, available: 02.10.2018

Gould D, Kelly D, Goldstone L, Gammon J (2001) Examining the validity of pressure ulcer risk assessment scales: developing and using illustrated patient simulations to collect the data. J Clin Nurs 10: 697-706. https://doi.org/10.1046/j.1365-2702.2001.00525.x

Hanzel A, Horvát K, Molics B, Berényi K, Németh B, Varga C (2018) Clinical improvement of patients with osteoarthritis using thermal/ mineral water at Szigetvár - results of a randomized double blind controlled study. Int J Biometeorol 62:253-259. https://doi.org/10. 1007/s00484-017-1446-6

Holló P, Bender T, Marschalkó M, Gonzalez R, Barna I, Horváth A (2004) No significant change of plasma beta-endorphin levels of psoriasis patients after synchronous balneophototherapy. Photodermatol Photoimmunol Photomed 20:205-209. https://doi. org/10.1111/j.1600-0781.2004.00105.x

Horvath K, Kulisch A, Nemeth A, Bender T (2012) Evaluation of the effect of balneotherapy in patients with osteoarthritis of the hands: a randomised controlled singleblind followup study. Clin Rehabil 26 : 431-441. https://doi.org/10.1177/0269215511425961

Karagülle M, Kardeș S, Karagülle MZ (2018) Long-term efficacy of spa therapy in patients with rheumatoid arthritis. Rheumatol Int 38:353362. https://doi.org/10.1007/s00296-017-3926-8

Kárpáti Z, Sajgó C, Vető I, Klopp G, Horváth I (1999) Organic matter in thermal waters of the Pannonian Basin - a preliminary report on aromatic compounds. Org Geochem 30:701-712. https://doi.org/ 10.1016/S0146-6380(99)00006-6

Kim YW (2018) Concurrent validity and clinical usefulness of universal plastic goniometer for hip internal and external rotation range measurement. J Korean Soc Phys Med 13:99-105. https://doi.org/10. 13066/kspm.2018.13.1.99

Kompanichenkoa NV, Poturaya AV, Karpov AG (2016) Organic compounds in thermal water: the Mutnovskii area and the Uzon caldera. J Volcanol Seismol 10:305-319. https://doi.org/10.1134/ S0742046316050031

Kovacs C, Pecze M, Tihanyi Á, Kovács L, Balogh S, Bender T (2012) The effect of sulphurous water in patients with osteoarthritis of hand. Double-blind, randomized, controlled follow up study. Clin Rheumatol 31:1437-1442. https://doi.org/10.1007/s10067-0122026-0

Kulisch A, Bender T, Németh A, Szekeres L (2009) Effect of thermal water and adjunctive electrotherapy on chronic low back pain: a double-blind, randomised, follow-up study. J Rehabil Med 41:7379. https://doi.org/10.2340/16501977-0291

Kulisch Á, Benkö Á, Bergmann A, Gyarmati N, Horváth H, Kránicz Á, et al (2014) Evaluation of the effect of Lake Hévíz thermal mineral water in patients with osteoarthritis of the knee: a randomized, controlled, single-blind, follow-up study. Eur J Phys Rehabil Med 50: 373-381

Lozano R, Naghavi M, Foreman K, Lim S, Shibuya K, Aboyans V, et al (2012) Global and regional mortality from 235 causes of death for 20 age groups in 1990 and 2010: a systematic analysis for the Global Burden of Disease Study 2010. Lancet 380:2095-2128. https://doi. org/10.1016/S0140-6736(12)61728-0

Marques AP, Marcolan JNO, Prado JNN, Burke TN, Ferreira EAG (2017) Inter- and intra-rater reliability of computerized 
photogrammetry and universal goniometer in the measurement of hip flexion and abduction. Fisioter Pesqui 24:22-28. https://doi.org/ 10.1590/1809-2950/15886624012017

Ministry of Health Decree no. 74/1999 (XII. 25.) on natural healing factors. Magyar Közlöny 1999. 122:8352-8363

Morer C, Roques CF, Françon A, Forestier R, Maraver F (2017) The role of mineral elements and other chemical compounds used in balneology: data from double-blind randomized clinical trials. Int J Biometeorol 61:2159-2173. https://doi.org/10.1007/s00484-017-1421-2

Musculoskeletal Health in Europe (2012) Report v5.0. European musculoskeletal conditions surveillance and information network

Nagy K, Berhés I, Kovács T, Kávási N, Somlai J, Bender T (2009a) Does balneotherapy with low radon concentration in water influence the endocrine system? A controlled non-randomized pilot study. Radiat Environ Biophys 48:311-315. https://doi.org/10.1007/s00411-009$0222-3$

Nagy K, Berhés I, Kovács T, Kávási N, Somlai J, Kovacs L, Barna I, Bender T (2009b) Study on endocronological effects of radon speleotherapy on respiratory diseases. Int J Radiat Biol 85:281290. https://doi.org/10.1080/09553000802512550

Pazira P, Rostami Haji-Abadi M, Zolaktaf V, Sabahi M, Pazira T (2016) The better way to determine the validity, reliability, objectivity and accuracy of measuring devices. Work 54:495-505. https://doi.org/ 10.3233/WOR-162310

Péntek M, Genti Gy, Pintye A, Ratkó I (1999) A WOMAC VA3.0 index magyar verziójának vizsgálata térd-és csípőarthrosisos betegeken. Magyar Reumatológia 40:94-97

Péter I, Jagicza A, Ajtay Z, Boncz I, Kiss I, Szendi K, Kustán P, Németh B (2017) Balneotherapy in psoriasis rehabilitation. In Vivo 31:1163-1168. https://doi.org/10.21873/invivo.11184
Pittler MH, Karagülle MZ, Karagülle M, Ernst E (2006) Spa therapy and balneotherapy for treating low back pain: metaanalysis of randomised trials. Rheumatology 45:880-884. https://doi.org/10. 1093/rheumatology/kel018

Rheault W, Miller M, Nothnagel P, Straessle J, Urban D (1988) Intertester reliability and concurrent validity of fluid based and universal goniometers for active knee flexion. Phys Ther 68:1676-1678. https:// doi.org/10.1093/ptj/68.11.1676

Soucie JM, Wang C, Forsyth A, Funk S, Denny M, Roach KE, Boone D (2010) Range of motion measurements: reference values and a database for comparison studies. Haemophilia 17:500-507. https://doi. org/10.1111/j.1365-2516.2010.02399.x

Suresh K (2011) An overview of randomization techniques: an unbiased assessment of outcome in clinical research. J Hum Reprod Sci 4:8 11. https://doi.org/10.4103/0974-1208.82352

Varga C (1991) Genotoxicologic evaluation of ozonated/chlorinated drinking water: cytogenetic effects of XAD-fractions on cultured human cells. Environ Toxicol Chem 10:1029-1035. https://doi. org/10.1002/etc.5620100807

Varga C (2010) Problems with classification of spa waters used in balneology. Health 2:1260-1263. https://doi.org/10.4236/health.2010.211187

Varga C (2012) Volatile organics in thermal spa waters: active ingredients or environmental toxicants? Thermae Spa Med 1(2):1-8

Varga C, Szuetta J (2009) A gyógyvizek új osztályozásának szükségességéről Balneológia. Gyógyfürdőügy, Gyógyidegenforgalom 28:7-12

WHO Department of Chronic Diseases and Health Promotion. Available at: http://www.who.int/chp/topics/rheumatic/en 